\title{
DETERMINATION OF FACTORS EXERTING INFLUENCE ON INVESTMENT BEHAVIOR WITH SPECIAL FOCUS ON WORKING WOMEN
}

\author{
Dr. Veena M \\ Assistant Professor, \\ Department of Commerce, \\ Vijayanagara Sri Krishnadevaraya Univrsity, \\ Ballari.
}

Article DOI: https://doi.org/10.36713/epra4971

\begin{abstract}
Investors are most important segment of financial markets. In fact, the vast majority of the money that is at work in the financial markets belongs to investors. Hence the stability of financial system and markets of any country depends on the decisions and behaviors of Investors at financial markets. The influence of retail increasing day by day as they have started to taking care of their portfolio's on their own. Hence it is imperative to have in-depth knowledge of factors exerting influence on investment behavior. According to previous research studies, investment behavior of individual investors is often influenced by set of factors. These factors may be internal or/and external environmental factors. The objective of this research paper was to identify the key factors influencing investment behavior investors with special focus on working women. The objective has been achieved with the help of previous empirical researches on women investment behavior and also confirmed through the survey results of the study conducted on 480 working women of Hyderabad Karnataka Region, Karnataka
\end{abstract}

KEY WORDS: Investment, Individual Investors, Investment Behavior, Factors influencing Investment Behvior etc.

\section{INTRODUCTION}

Investors are most important segment of financial markets. In fact, the vast majority of the money that is at work in the financial markets belongs to investors. Hence the stability of financial system and markets of any country depends on the decisions and behaviors of Investors at financial markets. There are many different investors that are active in the marketplace. The "Investor" can be an Individual, a Government or a Corporation.

Individual investors are individuals who are investing and managing their funds on their own. Individual investor is "An individual who purchases small amounts of securities for himself/herself, as opposed to an institutional investor.

Investors Behaviour has a significant influence on Stock market performance. The study "Quantitative Analysis of Investor Behaviour" conducted by
DALBAR Inc. (2016) ${ }^{17}$ Boston analysed investor return for 20 years of period from 1987 to 2006 for equity, fixed income and asset allocation funds, and the study concluded that investment return largely depends on investor behaviour.

At first, the influence of retail traders may seem small, but as time passes more people are taking control of their portfolios and, as a result, the influence of this group is increasing. Hence it is imperative to have in-depth knowledge of what investment behaviour is all about.

Investment Behaviour is defined as how the investors judge, predict, analyze and review the procedures for decision making, which includes investment psychology, information gathering, defining and understanding, research and analysis. The whole process is "Investment Behaviour" (Alfredo and Vicente, 2010) ${ }^{18}$. 
The term investment Behaviour can also be defined as portfolio practices, preferences, and investment intentions, pattern of investment and risk perceptions of investors. The Investor Behaviour is the process by which Investor tends to satisfy his/her needs by showing their choices.

\section{Indian Women and Investment}

21st century and Indian women have come a really long way in terms of empowerment and leaving their signs in the country. The status of women in India has been subject to many great changes over the few millennia. Today's women are outpacing men in several areas and have high offices including that of the president, Prime Minister, Chief Ministers and Governors of the states. There are $42.8 \%$ women who earn equal to or more than their husbands.

Surprisingly investing is one such area which still proves gender gap between men and women. Because, still there are women outside with low confidence and believe they have less knowledge about finance than men when it comes to investing. Few literatures on women finance literacy evidenced women consistently score lower than men on measures of financial literacy, and this gender-based gap can negatively impact the financial well-being of women.

However, few studies have been carried out on gender differences in investment behaviour and women investment behaviour, it was evidenced from those studies that women are more risk averse than men and thus when it comes to investing they invest more conservatively and less in amounts than men, frequency of investment in female is lesser when compared to the male (Dr. Monica Sharma, 2013). Working women are conservative in nature. And they lack the knowledge needed to make proper decision about their finance (Juwairiya P P, 2014). Social norms, family responsibilities have negative impact on investment activities of women (Diana J Beal et. al., 2015).

But, it is important to note that the studies on gender differences in investing have been mostly concentrated on data from developed countries, especially from the U.S. And it is widely acknowledged that women in developed countries differ drastically in many aspects, such as beliefs, life styles, behaviours, habits, personal characteristics, etc. and it may be expected that investment attributes of women living in developed countries differ from investment attributes of women living in the emerging and developing country like INDIA, where the status of women is typical.

Hence this study is the beacon of light in exploring the factors impacting on the financial well being of women and their Behavioral pattern. To the best of researcher's knowledge this is the first study exploring the investment Behaviours of women that provides evidence on this issue from an emerging country like India.

In consideration with the above discussion the topic of the present research is embodied as Determination of factors excerting influence on Investment Behaviour with special Focus on working women.

\section{OBJECTIVE OF THE STUDY}

The objective of the research was to identify the key factors influencing investment behaviour of working women. The objective has been achieved with the help of previous empirical researches on women investment behaviour (provided in chapter 2) and also confirmed through the survey results of the study (reported in chapter 5).

\section{IDENTIFICATION OF FACTORS INFLUENCING INVESTMENT BEHAVIOUR OF WORKING WOMEN}

Demographical factors play significant influence on investment behaviour of the investors (Dr. R Sellapan and Mrs. S Jamuna 2013). Among all the demographical factors, Age plays crucial role by influencing investment decisions of the investors. Risk temperament depends crucially on age and income. The level of education of women does influence behaviour. Highly qualified women may make better decisions while investing than the women with lower qualification. Security of funds and stable income are the desired requirements of married women whereas, unmarried women with less commitments may invest in risky assets. Married investors are conservative in nature than unmarried; women with more income may save more and invest more than women with less income. Likewise demographical factors affect differently to different persons.

A person with greater wealth takes greater risk (KathleenTerry, and Parker, 2002). Persons with upper level of income and millionaires tend to take higher risk than individual with lower level of income (MacCrimmon, and Wehrung, 1986). Researcher explored that level of risk tolerance increase with the increasing level of income (Friend I Blume et al.1994). Investors invest their funds in more volatile portfolio composed of more volatile stocks when they have higher level of income (Barber, and Odean , 2001). Higher level of income creates the ability of bearing the losses, so wealthier people preferred higher level of risk (Bayer and Bernheim et al, 2001, Dr. A Charles and Dr. R Kasilingam 2013)

. Majority of the women investing community are between the age group of 30 and 40 (LMA Preethi 
and Dr. Magesh Kuttalam 2014, Geetha and Ramesh 2012). There existed a close association between age and investment behaviour of working women. Education level, Awareness about the current financial system, Age of investors etc. make significant impact while making the choice of investment avenues (V.R.Palanivelu \& K.Chandrakumar 2013). Younger Investors are more interested in investment in comparison to elder and middle aged people (Heena Kothari) .

In the study conducted by Dr. Kuashal A Bhatt (2013), revealed that majority of the investors belong to the age group of 35 to 45 , and investors belong to this age group prefers to invest in stock markets. According to his study around $41 \%$ of investors were graduates, and those were interested to invest in stock market than the people belong to other categories of education. This study also revealed most of the investors were businessmen. Businessmen trade their stocks online in consultation with the advices of bankers and other investment professionals. Most of the businessmen are trading intraday and it is the highest number of people trading intraday.

Income and Occupation has significant impact on the behaviour of investors while making choice of Investment avenues. Higher income level people invest in equity stocks (D. Harikanth \& B. Pragathi 2012). Higher income group shows relatively high preference towards investment in share market, conversely lower and average income group show keen preference towards insurance and banks as the most preferred investment avenues (Ramanujam, $\mathrm{V}$ and Chitra Devi,K 2012).

A study was conducted by Mohammed Naumann Sadiq (2014) at Pakistan on a sample of 100 investors to examine the Effect of Demographic Factors on the Behaviour of Investors during the Choice of Investment. The study revealed positive correlation between Income level, education level and risk tolerance ability. The study revealed negative correlation between Income family sizes and risk tolerance ability. The study also found close association between marital status and risk tolerance ability of investors.

The significant effect of Demographic Factors and Awareness on Investment Behaviour of individual investors of stock market has been found in the study made by Arup Kumar Sarakar and Dr. Tharak Nath Sahu (2017) on 377 randomly selected investors at
West Bengal, Study indicated that people of ages between 28 years and 37 years invest more in the stock market.

Age, occupation, education, income and experience are the top five demographical factors which have significant influence on investment behaviour of investment decisions of the investors during buy, sell and hold shares during dividend declaration. The findings of his research revealed that all selected demographical variables have significant relationship with investment decisions to buy, sell and hold shares during dividend declaration (Zhobaida Khanam 2017).

As per the study conducted by Lutfi (2010) Investors' education and income positively correlated with the risk tolerance ability of the investors. The result of his study also revealed that investors' risk behaviour positively correlated with the type of investment they select. Risk seeking Investors prefer to invest most of their money in riskier assets, mainly stocks, and put the residual in other assets, such as bank accounts and real assets. In general, the risk seekers are those who are single, well educated, relatively wealthy, and small family investors.

Among all Demographical factors like investor's gender, age, marital status, education, and income were considered as most influencing factors of investment behaviour of the investors (Dr. Mandeep Kaur 2012). Demographic factors like age, marital status, gender, city, income level, market knowledge, occupations and qualifications etc have major impact on investment decision of investors (Dr. Dhiraj Jain 2012). Marital Status and gender and age negatively correlated with the investment decision whereas educational qualification and occupation of the investors positively correlated with the investment decisions of the investors.

Many research studies have been carried to examine the impact of demographical factors on the investment decision of the investors. In consultation with findings of these research studies demographical factors have considered as the most significant factors influencing investment behaviour of women.

Further, on this basis following 6 demographical factors have been considered for the study as independent factors: 


\section{Demographical Factors}

\begin{tabular}{|l|l|}
\hline SL.No. & Demographical Factors \\
\hline 1 & Age \\
\hline 2 & Marital Status \\
\hline 3 & Level of Education \\
\hline 4 & Occupation \\
\hline 5 & Income \\
\hline 6 & Family Size \\
\hline
\end{tabular}

Source: Created by the researcher

Demographical Factors and Investment Behaviour: Demographical factors are the characteristics of population. These include Age, Sex, Education, Marital Status, Income level, Family Size, profession, occupation, financial dependents etc. Generally the behaviour of persons can be affected by several factors. It can be different from person to person based on their Age, Sex, Education, Marital Status, Income level, Family Size, Profession, Occupation, Financial dependents etc. There are noticeable differences in investment decision between two persons from different economic groups. Many studies evidenced significant differences in the behaviour of investors with different demographics. Few such studies are summarised as follows:

Social Factors: There are certain factors that affect our thought and behaviour in social situations which are called as Social Factors.

Social Psychologists believed that behavioural outcomes are determined by individual acting in the context of their social context. Individuals often make their investment decisions based on their primary influence group. That is Friends, Family members, relatives and co-workers may influence women's financial decisions.

Financial decisions can be impacted by an individual's experience in financial markets, as well as those of that individual's peer group. Groups with more money to spend and a more sophisticated knowledge of investment instruments have more access to capital than those from different socio-economic groups. Knowing the comfort level of a particular market is important in designing products and services that meet its needs.

There are numerous instances proving the influence of these social factors on investment behaviour of individuals in general and countable studies on behaviour of women in particular.

Dr. Sindhu K.P and Dr. Rajitha (2014) Kumar have found in their study that majority of the investors depend on their brokers to decide where, when, how, and how much funds should be invested in different avenues.

Centre For Insurance Research (CFIR) conducted a study to examine the factors influencing investment behaviour of individual investors. The study revealed that Investors ranked Banking entities, Investment Depositories, Insurance Companies and Financial advisors as number 1, 2, 3 and 4 trustworthy agencies to make investment decisions. It has by the study of CFIR majority of the investors depended on banking entities to make their investment decisions.

Investors make decisions to buy sell and hold in response to the recommendations of financial analysts. Investors hold their securities on the hold recommendation, sell their securities or sell recommendation and buy securities or buy recommendations by the financial analysts. Majority of the investors buy their stocks through individual stock brokers (Ambrose Jagongo et.al). Recommendations from friends or co-workers have been marginally loaded on this factor as well in previous research studies.

The study conducted by Arian Borgers (2015), was aimed at clarifying the economic significance of social dimensions in investment decisions. The study was conducted on US equity Mutual fund holders. Their study found that US equity mutual fund investors were responsive to the local political, religion and social environment. The study concluded that investors were socially conscious in making their investment decisions. Among all social factors, one of the most influencing factors of investment behaviour of the investors is influence of family members (Dr. Mandeep Kaur 2012).

A study was conducted by Anna A. Merikas and Andreas G Merikas (2013), attempted to study the impact of economic factors on individual investor behaviour, in Greeck Stock Exchange. Their study considered factors relating to accounting information, family factors and other political influence on investment behaviours of investors.

In the study conducted by Bouteska Ahmad S (2015), it has been found that nearly $30.9 \%$ of the investors were influenced by the family members' opinion. And the author also concluded that broker recommendation is the most influencing factor of investment behavior. 
In consultation with these studies following for the present study: social factors were considered as independent factors

Social Factors

\begin{tabular}{|l|l|}
\hline SL No & Social Factors \\
\hline 1 & House Hold financial needs and daily money Management \\
\hline 2 & Family influence on decision making \\
\hline 3 & Family members opinion on Investment \\
\hline 4 & Sources of Financial Information \\
Source: Created by the researcher
\end{tabular}

Psychological Factors: Individuals behaviour is influenced by many factors some are internal and some are external. There are certain factors which are individual itself; those significantly affect the behaviour of the investors. These factors are called Psychological factors. Psychological factors are the factors that drive individuals' action and seek satisfaction. Many studies witnessed the significant influence of psychological factors on investment behaviour of individuals in general and in particular with women. The findings of few such studies are summarized as follows:

Kadijeh Ebrrahimi and Mohsen Dastgir (2016), have tested the relationship personality characteristics and Investment trends of Capital Market Analyst, and their study showed the significant correlation extraversion, agreeableness and consciousness on risk aversion. In addition, no significant negative relationship was found by the author between risk aversion and analyst's tendency of investment.

Gender has significant influence on psychological factors of women, further both gender and psychological factors significantly influence the investment behaviour of investors. women are more risk averse than men even when they have sufficient investment knowledge and experience (Jenna Fish 2012).

Five big traits like consciousness, Openness to experience and agreeableness had direct positive impact on investment performance (as identified by psychologists) have significant impact on investment behaviour of investors (Phung Thai Minh Trang and Mai Ngoc Khuong).

\section{Psychological Fac}

\begin{tabular}{|l|l|}
\hline Sl. No. & Psychological Factors \\
\hline 1 & Confidence Level \\
\hline 2 & Investor Optimism \\
\hline 3 & Investor Conservatism \\
\hline 4 & Investor Beliefs \\
\hline
\end{tabular}

Other Factors: there are several factors apart from the factors discussed so far, that have significant impact on investment behaviour of the investors. Among all
Investors driven by objectives related to speculation have higher aspirations and turnover, take more risk, judge themselves to be more advanced, and underperform relative to investors driven by the need to build a financial buffer or save for retirement (Arvid O. I. Hoffmann, Hersh Shefrin and Joost M. E. Pennings).

. Among all factors Psychological factors were considered as the significant factors influencing investment behaviour of the investors. Confidence level, dependency level, desires, goals, prejudices, biases, emotions and beliefs were identified as psychological factors influencing investment behaviour of the investors (Dr. Mandeep Kaur 2012). Herding has negative influence on choice of Investment Avenue. Over confidence has negative impact on investment behaviour of investors. Anchoring has positive influence on choice of investment avenues (Lingesiya Kengatharan and Navaneethakrishnan Kengatharan 2014).

Lubna Riaz, Ahmed Imran Hunjra and Rauf-iAzam (2012), have considered investment decisions of investors as dependent variable while risk propensity, problem framing, asymmetry of information, confidence level were considered as Independent variables. And their study found the significant association among them. investor optimism is the key factor in making investment decision of investors at equity markets ( $\mathrm{R}$. Jayaraman and Dr. G Vasanthi (2014).

In consultation with these studies following psychological factors are identified as most significant factors influencing investment behaviour of the working women and are considered for the present study:

other Accounting information is the most significant one. In the present study accounting information was considered under "Other" group category in 
consultation with the empirical findings of following studies.

Hussein A. Hassan Al-Tamimi (2012), again it has proved from the study expected corporate earnings, get rich quick, stock marketability, past performance of the firm's stock, government holdings and the creation of the organized financial markets have significant influence on investment behaviour. Moderately influencing factors in order of importance were: expected losses in other local investments, minimizing risk, expected losses in international financial markets, family member opinions, gut feeling on the economy. Religious beliefs and family members' opinion were proved as least bothering factors according to his study.

It has been found from the study conducted by Dr. Shaffeq Ahmad(2017), around $76.47 \%$ and $72.4 \%$ of investors consider expected earnings of the company and Dividend payment while making investment decisions respectively. Another $68.62 \%, 65.68 \%$ and $63.72 \%$ of the respondents were influenced by stock marketability, financial statements and expected dividends of the company respectively. So from these statistics it can be concluded that accounting information plays vital role in investment behaviour of the investors. It has been found that annual reports of the company are the major source of information to the investors (G. Gniewosz 1990). And the accounting information is considered as the most useful information to make investment decisions.

With reference to these studies accounting information was considered as one of the factors influencing investment behaviour of the investors under the category of other factors. Opinion survey of respondents on the following factors of accounting information was made in the present study:

Other Factors

\begin{tabular}{|l|l|}
\hline \multicolumn{2}{|l|}{ Factors relating to accounting information } \\
\hline $\mathbf{1}$ & Fundamental factors \\
\hline 1.1 & Past performance of the company \\
\hline 1.2 & Financial Position of the company \\
\hline 1.3 & Earnings of the Company \\
\hline 1.4 & Dividend Payment \\
\hline 1.5 & Risk return factors of the stock \\
\hline 1.6 & Share Price in the market \\
\hline 1.7 & Credit rating \\
\hline 1.8 & Capital structure of the company \\
\hline 1.9 & Quality of Management \\
\hline 1.10 & Brand and reputation of the Co. \\
\hline 1.11 & Listing of co. on stock exchange \\
\hline 1.12 & Marketability of stock \\
\hline 1.13 & CSR practices of the Co. \\
\hline 2 & Technical factors \\
\hline 2.1 & Past price movements \\
\hline 2.2 & Daily price movements \\
\hline 2.3 & Use of charts, trends and patterns \\
\hline 2.4 & Active trading volume of the stock \\
\hline 3 & Market information \\
\hline 3.1 & News about stock in media and market \\
\hline 3.2 & Current market trends \\
\hline 3.3 & Recommendations of professionals, family, friends and peer \\
\hline Source: Created by the researcher \\
\hline
\end{tabular}

\section{FACTOR ANALYSIS}

Factor analysis is a useful tool for investigating variable relationships for complex concepts including behavioural patterns. It involves grouping similar variables into dimensions. It helps the researcher to evaluate the concepts that are not easily measured by collapsing a large number of variables into a few interpretable variables. It is used as a data reduction method. But most importantly it is often used to determine a linear relationship between variables before subjecting them to further analysis. The relationship of each variable to the underlying factor is expressed by the factor loadings.

The present work used exploratory factor analysis to extract maximum variance from the data set of 60 variables and to reduce a large number of 
variables down to a smaller number of components/clusters.

Generally accepted criteria for factor analysis is Eigen Values of greater than 1.0 and factor loading of 0.5 were considered in this study. Kaiser (1974) pointed that KMO measures sampling adequacy which is greater than 0.5 as acceptable. Furthermore, the Bartlett's Test of Sphericity is highly significant at $p$ value less than $0.001(\mathrm{p}<0.001)$. Identification factors influencing investment behaviour of the study followed the above criteria for conducting Exploratory Factor analysis.

Results of Exploratory Factor Analysis Matrix of Factors influencing Investment Behavior of selected Working Women (Independent Variables)

\begin{tabular}{|c|c|c|}
\hline $\begin{array}{l}\text { Factors } \\
\text { Identified }\end{array}$ & Constructs & $\begin{array}{l}\text { Factor } \\
\text { Loadings }\end{array}$ \\
\hline \multirow{8}{*}{ Factor 1} & Brand and reputation of the Co. & 0.612 \\
\hline & Marketability of stock & 0.835 \\
\hline & CSR practices of the Co. & 0.811 \\
\hline & Past price movements & 0.854 \\
\hline & Daily price movements & 0.623 \\
\hline & Use of charts, trends and patterns & 0.634 \\
\hline & Current market trends & 0.616 \\
\hline & Reputation of the firm & 0.614 \\
\hline \multirow{4}{*}{ Factor 2} & Dividend Payment & 0.245 \\
\hline & Quality of Management & 0.592 \\
\hline & Listing of co. on stock exchange & 0.516 \\
\hline & Active trading volume of the stock & 0.598 \\
\hline \multirow{5}{*}{ Factor 3} & I have complete knowledge of Financial instruments available at stock markets & 0.621 \\
\hline & I am satisfied with my present financial position & 0.695 \\
\hline & I am confident that I have secure financial future & 0.523 \\
\hline & I have clear plans for my future retirement life & 0.601 \\
\hline & Investment is exciting and satisfies financial needs. & 0.758 \\
\hline \multirow{4}{*}{ Factor 4} & I increase my investment in Stocks & 0.839 \\
\hline & I hold my investment in stock market for long time & 0.781 \\
\hline & The prices of my securities will increase in future & 0.862 \\
\hline & I do not hesitate to invest in new securities & 0.757 \\
\hline \multirow{2}{*}{ Factor 5} & Perceived ethics of firm & 0.806 \\
\hline & Firm position in industry & 0.666 \\
\hline \multirow{2}{*}{ Factor 6} & $\begin{array}{l}\text { I rely on fundamental analysis to take investment decision(Economy, Industry and } \\
\text { Company analysis) }\end{array}$ & 0.826 \\
\hline & $\begin{array}{l}\begin{array}{l}\text { I rely on Past performance and Price movements to take investment } \\
\text { decision(Technical Analysis) }\end{array} \\
\end{array}$ & 0.814 \\
\hline \multirow{3}{*}{ Factor 7} & I take investment decisions based on my emotions & 0.546 \\
\hline & I am responsible for my financial well being & 0.745 \\
\hline & I need to plan for my financial future & 0.776 \\
\hline \multirow{2}{*}{ Factor 8} & Past performance of the company & 0.798 \\
\hline & Share Price in the market & 0.611 \\
\hline \multirow{2}{*}{ Factor 9} & Does your family influence your investment decision? & 0.594 \\
\hline & Recommendations of professionals, family, friends and peer & 0.593 \\
\hline Factor 10 & Financial Position of the company & 0.736 \\
\hline
\end{tabular}


EPRA International Journal of Multidisciplinary Research (IJMR) - Peer Reviewed Journal Volume: 6 | Issue: 8 | August 2020 || Journal DOI: 10.36713/epra2013 || SJIF Impact Factor: 7.032 ||ISI Value: 1.188

\begin{tabular}{|l|l|l|}
\hline \multirow{2}{*}{ Factor 11 } & I depend on my spouse to take investment decision & 0.754 \\
\cline { 2 - 3 } & I don't wish to take any financial responsibilities & 0.596 \\
\hline \multirow{2}{*}{ Factor 12 } & Dividend Payment & 0.548 \\
\cline { 2 - 3 } & Risk return factors of the stock & 0.777 \\
\hline Factor 13 & I invest in companies with stable returns & 0.794 \\
\hline Factor 14 & I don't have any financial needs to be satisfied through investment income & 0.832 \\
\hline Factor 15 & It is important to setup clear financial goals with timelines & 0.521 \\
\hline & Investment is a man's job & 0.771 \\
\hline Factor 16 & Investment is time consuming, difficult and stressful & 0.605 \\
\hline Factor 17 & Who manages your investment? & 0.868 \\
\hline
\end{tabular}

Seventeen constructs have been identified through factor analysis. These include:

1. Accounting information of the company

2. Stock market information

3. Financial Position and plans

4. Investment Optimism

5. Co. specific factors

6. Fundamental factors

7. Beliefs

8. Market Performance
9. Family and Peer group

10. Financial position

11. Dependency

12. Returns

13. Performance stability

14. Financial needs

15. Investment goals

16. Investment sentiments

17. Investment management

Results of KMO and Barlett's Test

\begin{tabular}{|l|l|l|}
\hline \multicolumn{2}{|l|}{ KMO and Barlett's Test } \\
\hline KMO measure of sampling adequacy & 0.519 \\
\hline Total Variance Explained & 77.839 \\
\hline \multirow{3}{*}{ Barlett's test of sphericity } & Approximate Chi-square & 27009.414 \\
\cline { 2 - 3 } & DF & 1770 \\
\cline { 2 - 3 } & P value & 0.000 \\
\hline
\end{tabular}

Source: Created by the researcher

The above table shows the result of two tests say Kaiser-Meyer-Olkin (KMO) measure of sampling adequacy and Barlett's test of sphericity that indicates the proportion of variance caused by the underlying factors on the variables. The KMO value of 0.519 indicates factor analysis is useful with the data.

Barlett's test of Sphericity tests the hypothesis that correlation matrix is an identity matrix which could indicate variables that are unrelated and therefore unsuitable for structure detection. $\mathrm{P}$ value of 0.000 indicates (generally $\mathrm{P}<.05$ ) factor analysis is useful with the data.

\section{SUMMARY OF FINDINGS IN TERMS OF FACTORS IDENTIFIED}

The objective of identification of factors influencing investment behavior of working women was achieved through the extensive review of existing literature on investment behavior of investors. Following factors have been identified as most influencing factors of investment behavior of working women:

Demographical factors - Age, Marital Status, Level of Education, Occupation, Income and
Family Size (McCrimmon, and Wehrung, 1986, Blume et al.1994, Barber, and Odean , 2001Terry, and Parker, 2002, Preethi and Dr. Magesh Kuttalam (2014), Geetha and Ramesh (2012) Dr. A Charles and Dr. R Kasilingam, V.R.Palanivelu \& K.Chandrakumar (2013), Heena Kothari, by Dr. Kaushal A. Bhatt, by Dr. D. Harikanth \& B. Pragathi (2012), Mhammed Naumann sadiq (2014))

Social Factors - Influence of Family, Family members opinion, Recommendations of Brokers and investment professionals, friends and peer group (Dr. Sindhu K.P and Dr. Rajitha Kumar, Centre for insurance research (CFIR), Ambrose Jagongo and Vincent S. Mutswenje, Arian Borgers, Jeroen Derwall, Kees Koedijk, and Jenke ter Horst, Dr. Mandeep Kaur (2012), Anna A. Merikas and Andreas G Merikas (2013), Ahmad S 2017).

Psychological Factors - Confidence Level, Investor Optimism, Investor Conservatism and Investor Beliefs (Kadijeh Ebrrahimi and Mohsen Dastgir, Jenna Fish, Phung Thai Minh Trang and Mai Ngoc Khuong, Arvid O. I. Hoffmann, Hersh Shefrin and Joost M. E. Pennings, Dr. Mandeep Kaur (2012), Lingesiya Kengatharan and Navaneethakrishnan Kengatharan, 
Lubna Riaz, Ahmed Imran Hunjra and Rauf-i-Azam, R. Jayaraman and Dr. G vasanthi).

Other Factors - Accounting Information (G. Gniewosz Hussein A. Hassan Al-Tamimi(2012) Dr. Ahmad(2017), )

\section{Reference Studies}

The brief demographical and investment profile of Working women selected for the study has been presented in the paper entitled "Investment Profile of Working Women of Hyderabad Karnataka Region" EPRA International Journal of Economic and Business Review-Online ISSN 2347$9671 \&$ Print ISSN 2349-0187, Volume 7, Issue 2, 17th February 2019.

The Impact of the identified factors also presented in the other research papers.

\section{REFERENCES}

1. Robert Christopher Hammond, "Behavioural Finance - Its History and Its Future”, Fire Scholars, South Eastern University, Lakeland

2. Arvid $O \quad I$ Hfmann And Hersh Shefrin, "Behavioural Portfolio Analysis of Individual Investors"

3. Nathalie Abi Saleh Dargham, "The Implications Behavioural Finance"

4. Gefrey Gitau Mwangi, "Behavioural Factors Influencing Investment Decisions in the Kenyen Property Market", Thesis Submitted to Strathmore University, Keynya

5. Federal Research Division, "Customised Research and Analytical Services of US Government"

6. L.M.A. Preethi and Dr. Magesh Kuttalam (August 2014), "Influence Personality and Demographics in Investment Choice", International Journal of Applied Research and Studies, ISSN: 2278-9480 Vol. 3, Issue 8

7. Brahmabhatt, P.S Raghu Kumari and Dr. Shamira Malekar (September 2012), '”A Study of Investor Behaviour on Investment Avenues in Mumbai Fenil", Trans Asian Journal Marketing \& Management Research Vol.1 Issue 1

8. Khoa Cuong Phan, Jian Zhou (2014), "Factors Influencing Individual Investor Behavior: An Empirical Study The Vietnamese Stock Market", American Journal Business and Management, Vol. 3, No. 2, 77-94

9. Dr. K Ravichandran (July-2008), "A Study on Investors Preferences towards Various Investment Avenues in Capital Market with Special Reference to Derivatives", Journal of Contemporary Research In Management

10. Pr. Gouri Prabhu And Pr. NM Vechlekar "Perception Indian Investors Towards Investment In Mutual Funds With Special Reference To MIP
Funds", IOSR Journal Economics And Finance PP 66-74

11. Geetha, N., \& Ramesh, M. (2012), “A Study on Relevance Demographic Factors In Investment Decisions", Perspectives of Innovations, Economic \& Business , 14-27.

12. Ramanujam, K., \& Devi, K. (2012). "A Study on Impact Socio-Economic Profile on Investment Pattern Salaried \& Business People in Coimbatore City" International Journal Management \& Information Technology, 67-77

13. T. Velmurugan, And N. Vijai Anand (2015), "A Study On Factor Influencing Mutual Fund Investment - Special Reference to Investor in Pharmaceutical Sector At Chennai Metro City", Int. J. Pharm. Sci. Rev. Res., 34(1)

14. Ambrose Jagongo and Vincent S. Mutswenje (2014), "A Survey of the Factors Influencing Investment Decisions: The Case of Individual Investors at The NSE”, International Journal Humanities And Social Science, Vol. 4 No. 4

15. Samreen Lodhi (2014), "Factors Influencing Individual Investor Behavior: An Empirical Study City Karachi”, IOSR Journal of Business and Management (IOSR-JBM), E-ISSN: 2278-487X, PISSN: 2319-7668. Vol. 16, Issue 2. Ver. III

16. Neha Parashar, "Factors Affecting Perception Investors on Mutual Funds", Symbiosis Centre Management, Maharashtra

17. Anna A Merikas and Andreas $G$ Merikas, "Economic Factors and Individual Investor Behaviour: The Case of the Greek Stock Exchange", Journal of Applied Business Research, Vol. 20, Number 4

18. Hussein A. Hassan Al-Tamimi, "Financial Literacy And Investment, Decisions of US Investors", Www.Emeraldinsight.Com

19. Dr. R Sellappan and Jamuna "Investment Attitude of Women towards Different Sources of SecuritiesA Factor Analysis Approach", Global Journal Management And Business Research Finance, Vol. 13 Issue 3

20. Dr. Mandeep Kaur And Tina Vohra (December 2012), "Understanding Individual Investors Behaviour- A Review Empirical Evidences", Pacific Business Review International, Vol. 5, Issue 6

21. Abhijeeth Chandra And Ravindra Kumar(2011), "Determinants Individual Investor Behaviour: An Orthogonal Linear Transformation Approach", Munich Personal Rep Eo Archieve, Paper No. 29722

22. Dr. Hayat A Awan and Shanza Arshad (May 2012), "Factors Valued By Investors While Investing in Mutual Funds- A Behavioural Context", International Journal of Contemporary Research In Business, Vol. 4, No. 1

23. Olsen Robert (2010), "Toward A Theory Behavioural Finance - Implications from the Natural Sciences", Conceptual Paper Published in 
Qualitative Research in Financial Market, Emerald Group Publishing Limited

24. Iqbal Mahmood, H. A. (2011). "Behavioural Implications Investors for Investments in the Stock Market”, European Journal of Social Science, No. 20

25. Suleyman Gokhan Gunay, E. D. (2011). "Interaction Between Demographic and Financial Behaviour Factors in Terms of Investment Decision Making”, International Research Journal Finance And Economics (66), 1450-2887

26. Phung Thai Minh Trang And Mai, "The Impact of Big Five Traits and Mood on Investment Performance - A Study of Individual Investors In Vietnam"

27. Kadijeh Ebrrahimi and Mohsen Dastgir (September 2016), "The Effect of Personality Characteristics of Capital Market Analysis on Investment Trends, Risk and Return and their Performance", Article 3, Vol. 1, Issue 2

28. Haritha PH and Rashmi Uchil, "Conceptual Framework on Market Factors Influencing Investors Sentiments and Effect of Behavioural Pitfalls on Investment Decision", IOSR Journal Economics and Finance, PP 29-34

29. Dr. Gagan Kukreja (Dec. 2012), “Investors Perception for Stock Market- Evidences from National Capital Region of India", Interdisciplinary Journal of Contemporary Research in Business, Vol. 4, No.8

30. Bhuvaneshwari C, "A Study on Investors Perception towards Equity/Tax Saving Mutual Fund", International Journal of Engineering and Management

31. Murat Kiyllar and Ocan Acar , "Behavioural Finance and the Study of the Irrational Financial Choices of Credit Card Users", Annales University Apulensis Series Oeconomica, 11(1)

32. Mehmet Islamoglu, Mehmet Apan, and Adem Ayvali (2009), "Determination of Factors Affecting Individual Investor Behaviours: A Study on Bankers", International Journal of Economics And Financial Issues, 5(2), 531-543.

33. Anna A Merikas and Andreas $G$ Merikas, "Economic Factors and Individual Investor Behaviour: The Case of the Greek Stock Exchange", Journal of Applied Business Research, Vol. 20, No.4

34. Arvid O I Hfmann, Hersh Shefrin and Joost ME Pennings, "Behavioural Portfolio Analysis of Individual Investors", Report Submitted to Maastricht University, School Business and Economics, Netherland

35. Jenna Fish (2012), "Behaviour Finance- A Study Gender Affects on Investment Decisions", Report, Calrson School Management, University Minnesota, Spring

36. Black et al, "Capital Investment Effects Dividend Imputation", The Journal of American Taxation Association, PP40-59
37. Anna Merikas (Ocober 2004), "Economic Factors and Individual Investor Behaviour - The Case of the Greek Stock Exchange”, Journal of Applied Business Research

38. Ranjani Krishnan and Donna M Brooker (Feb 2002), "Investors Use of Analysts' Recommendations", American Accounting Association, Vol. 14, Issue 1

39. Syama Sundar P V, "Growth Prospects of Mutual Funds and Investor Perception With Special Reference to Kothari Pioneer Mutual Fund", Project Report, Sri Srinivas Vidya Parishad, Andhra University, Vishakpatnam

40. R Suyam Praba (2016), "An Empirical Study on Gender Difference in the Investment Pattern of Retail Investors" Acme Intellects International Journal Research in Management, Social Sciences \& Technology, Vol. 14

41. Priyanka Pandey (May-2014), "A Study of Gender Biasness in Investment Behaviour of Investor", Golden Research Thoughts, Vol.-3 Issue-11

42. Madhurima Deb and Kavita Chavali (July 2009), "A Study on Gender Differences in Investment Behaviour", Asia Pacific Journal of Management Research and Innovation, Vol. 5 No. 3 45-55

43. Dr. Monica Sharma And Dr. Vani Vasakarla (July 2013), “ An Empirical Study of Gender Differences in Risk Aversion and Overconfidence in Investment Decision Making", International Journal of Application or Innovation in Engineering \& Management (IJAIEM), Vol. 2, Issue 7

44. Iowa State University Report On "Gender Differences in Investment Behaviour"

45. Rebecca Sophia Meade, "Women, Micro Finance and Saving-Lessons and Proposals", Centre For Social Development, Washington University

46. Arti Gaur, Julee and Sunitha Sukhija (2011), "Difference in Gender Attitude in Investment Decision Making in India", Research Journal of Finance and Accounting, Vol. 2, No. 12

47. Michael Liersch (2009), "Women and Investing -A Behavioural Finance Perspective", Journal of Economic Literature

48. Vickie L Bajtelsmit and Alexander Bernasek (1996), "Why Do Women Invest Differently than Men", Association for Financial Counselling and Planning Education

49. Matthais Gysler, Jamie Brown and Renate Schubert (May 2002), "Ambiguity and Gender Differences in Financial Decision Making- An Experimental Examination Competence and Confidence"

50. Annika E Sunden and Brain J Surette (1998), "Gender Differences in the Allocation of Assets in Retirement Saving Plans", American Economic Review, Vol. 88, Issue 2, PP 207-211

51. Elezebeth Mcbride (Jan 2015), "Emotions CountBrain Chemistry Behind Investing", WWW. Goarticles.Com

52. Gert Abraham Lowies, John Henry Hall and Christian Ernst Cloete (2012), "The Role of 
Behavioural Aspects in Investment Decision Making By Listed Property Fund Managers in South Africa", Master Thesis, University Pretoria

53. Mohd Abass Bhat and Fayaz Ahmad Dar, "A Conceptual Framework on Emotions and Investment Decisions", National Monthly Refereed Journal Research in Commerce \& Management

54. Yu-Je Lee and Kae-Shuan Kao, "The Investment Behaviour, Decision Factors and their Effects Toward Investment Performance in the Taiwan Stock Market".

55. Zipporah Nyaboke Onsomu (Jun 2014), "The Impact of Behavioral Biases on Investor Decisions in Kenya: Male Vs Female”, International Journal of Research in Humanities, Arts And Literature, Vol. 2, Issue 6, 87-92.

56. Dhimen Janil and Dr. Rajeev Jain(March'13), "A Comparative Analysis of Investors Buying Behavior Urban Rural For Financial Assets", International Monthly Refereed Journal of Research in Management \& Technology, Vol. II

57. Gnani Dharmaja .V, Ganesh .J, and Dr. Santhi V (April 2012), "A Study on the Individual Investor Behaviour With Special Referance to Geojit BNP Paribas Financial Service Ltd, Coimbatore", IRACST- International Journal Research In Management \& Technology (IJRMT), ISSN: 2249 9563 Vol. 2 No. 2

58. Baba Shiv, G. L. "Investment Behaviour and the Negative Side of Emotion" American Psychological Society, 16, 435- 439

59. Barber, B M \& Odean, T (2001), 'Boys Will Be Boys: Gender, Overconfidence, and Common Stock Investment', The Quarterly Journal of Economics, Vol.116, No.1

60. Shlomo Benartzi and Thaler (March 2013), "Behavioural Economics Aand the Retirement Savings Crisis", Policy Forum, Vol. 339

61. Gervais And Odean (2008), "All the Glitters, the Effect Attention and News on the Buying Behaviour of Individual and Institutional Investors", The Review of Financial Studies, Vol. 21, No.2

62. Daniel and Huberman, "Familiarity Breeds Investment" The Review of Financial Studies, Vol. 14, No.3, 659-680."

63. Pasewark, W. R., \& Riley, M. E. "It's A Matter of Principle: The Role of Personal Values in Investment Decisions", Journal of Business Ethics , 237-253, 2009

64. Sharon Collard (January 2009), Personal Finance Research Centre, University Bristol, "Individual Investment Behaviour: A Brief Review of Research", Final Report,

65. Fischer, Rene, and Ralf Gerhardt (2007), "Investment Mistakes of Individual Investors and the Impact of Financial Advice”, European Business School Working Paper

66. Brown, G.W. and Michael T. Cliff (2004), "Investors Sentiment and the Near-Term Stock
Market", Journal of Empirical Finance, Vol. 11, Pp. 1-27

67. Heena Kothari, "Individual Investors Behaviour towards Financial Decision Making: A Conceptual Model", Altius Shodh ISSN 2348-8891

68. Sumathi.S, Thirumagal Vijaya .M January (2015), "A Study on Investment Behaviour of Women Employees in Coimbatore City", Excel International Journal of Multidisciplinary Management Studies, Vol.5 (1), Pp.82-89

69. Ramanujam, V., \& Ramkumar, G. (2012), “An Empirical Analysis On Preferred Investment Avenues Among Young and Experienced Women Investors with reference to Coimbatore". International Journal of Business and General Management, PP 3-11

70. Juwairiya.P.P (July 2014), “ Financial Literacy and Investment Pattern of Working Women in Kerala”, International Journal of Marketing, Financial Services \& Management Research, IJMFSMR, Vol.3 (7), Pp. 24-33

71. Diana Fletschner And Lisa Kenney, "Rural Women's Access to Financial Services- Credit, Savings and Insurance" 